University for Business and Technology in Kosovo

UBT Knowledge Center

UBT International Conference

2012 UBT International Conference

Nov 2nd, 9:00 AM - Nov 3rd, 5:00 PM

\title{
Impact of Collective Residential Building in Environmental Sustainability of Cities in region
}

\author{
Ferhat Bejtullahu \\ University for Business and Technology, bejtullahu@ubt-uni.net
}

Follow this and additional works at: https://knowledgecenter.ubt-uni.net/conference

Part of the Architecture Commons

\section{Recommended Citation}

Bejtullahu, Ferhat, "Impact of Collective Residential Building in Environmental Sustainability of Cities in region" (2012). UBT International Conference. 3.

https://knowledgecenter.ubt-uni.net/conference/2012/all-events/3

This Event is brought to you for free and open access by the Publication and Journals at UBT Knowledge Center. It has been accepted for inclusion in UBT International Conference by an authorized administrator of UBT Knowledge Center. For more information, please contact knowledge.center@ubt-uni.net. 


\title{
Impact of collective residential buildings in Environmental Sustainability of Cities in region (Prishtina)
}

\author{
Ferhat Bejtullahu $^{1}$ \\ ${ }^{1}$ University for Business and Technology, Department of Architecture \\ Ferhat.bejtullahu@ubt-uni.net
}

\begin{abstract}
Cities in region haze experienced social disturbances. War, crime and corruption divert resources from areas of greatest human need; damage the capacity of societies to plan for the future, and generally threat human well-being and the environmental sustainability.

Sustainability is studied and managed over many scales of time and space and in many contexts of environmental, social and economic organization. The focus of this study is on Environmental Sustainability of Cities in region thru impact of collective residential buildings in neighborhoods, occupations, lifestyles, behavior patterns and so on. Best international approaches and principles will be analyzed and compared with regional trends.

Many approaches, lightly constructed around new urbanism, are effectively reducing environmental impacts by changing the built environment to create and preserve sustainable cities which support sustainable transport. Residents in compact urban neighborhoods drive less, and have significantly lower environmental impacts across a range of measures, compared with those living in sprawling suburbs.

This paper attempts to identify positive and negative impact of actual trend in building collective residential buildings in cities of region with focus in Prishtina.

The specific objective of this paper is to find and suggest solutions of planning approaches to the architectural designs that will have positive impact on Environmental Sustainability of Cities in region (Prishtina).

The paper finally will suggest principles that will serve as policies to the new approach in process of design, creation and maintenance of build environment that can contribute to the Environmental Sustainability of Cities in region.

Concluding that this paper is just starting point in integrative development process to the socially inclusive and environmental friendly cities. I hope that this paper will be used by architects, environmentalists and urban designers as guideline of future research in this field.
\end{abstract}

Keywords : residential, sustainability, environment, urban, trends

\section{INTRODUCTION}

\subsection{Definitions :}

Environment and healthy ecosystems present vital resources and processes. There are two major ways of managing human impact on environment and its sustainability. One approach is environmental management; another approach is management of consumption of resources, which is based largely on information gained from educated professionals. This paper is focused on study of Environmental Sustainability of Cities in region thru impact of Collective Residential Buildings (CRB) as an important part of consumption of resources.Collective Residential Buildings (CRB) In Official Journal of the European Union are named -Apartment blocks/multi-family buildings)

Sustainability is studied and managed over many scales of time and space and in many contexts of environmental, social and economic organization. The focus ranges from the total carrying capacity of planet Earth to the 
sustainability of economic sectors, ecosystems, countries, municipalities, neighborhoods, home gardens, individual lives, individual goods and services, occupations, lifestyles, behavior patterns and so on. In short, it can entail the full compass of biological and human activity or any part of it. Daniel Botkin, author and environmentalist, has stated: "We see a landscape that is always in flux, changing over many scales of time and space."

The underlying driver of direct human impacts on the environment is human consumption. This impact is reduced by not only consuming less but by also making the full cycle of production, use and disposal more sustainable. Consumption of goods and services can be analyzed and managed at all scales through the chain of consumption, starting with the effects of individual lifestyle choices and spending patterns, through to the resource demands of specific goods and services, the impacts of economic sectors, through national economies to the global economy. Analys is of consumption patterns relates resource use to the environmental, social and economic impacts at the scale or context under investigation. The ideas of embodied resource use, resource intensity, and resource productivity are important tools for understanding the impacts of consumption. Key resource categories relating to human needs are food, energy, materials and water.

Research also shows that the best intelligence in buildings resides with the occupants.( Brand, Stew art) If so, the challenge for designers and manufacturers is to support them with appropriate and understandable systems which have readily-usable control interfaces, and which give immediate feedback on their performance.

Given the inherent problems of operating mechanical building services in regions of the world where energy sources may be unreliable, along with the likely lack of engineering skills to maintain those services, it makes sense to adopt passive solutions wherever possible. The most obvious approach is to use the building fabric as a medium for storing, cooling and heating energy. (Rawlings, R. 1999)

Construction materials and products are essential to life as we know it - with respect to both buildings and infrastructure. Humans spend around $80 \%$ of their time (on average) in some type of building or on roads. Construction products play a major role in improving the energy efficiency of CRB buildings and contributing to environmental sustainability of cities.

On the other hand, construction products also have a considerable impact on the environment. According to one source, the construction sector is responsible for $50 \%$ of the material resources taken from nature and $50 \%$ of total waste generated.(Anink, D., 1996)

In 2010, the International Resource Panel, hosted by the United Nations Environment Programme, published the first global scientific assessment on the impacts of consumption and production and identified priority actions for developed and developing countries. The study found that the most critical impacts are related to ecosystem health, human health and resource depletion. From a production perspective, it found that fossil-fuel combusting processes, agriculture and fisheries have the most important impacts. Meanwhile, from a final consumption perspective, it found that household consumption related to mobility, shelter, food and energy-using products cause the majority of life-cycle impacts of consumption.

Historically there has been a close correlation between economic growth and environmental degradation: as communities grow, so the environment declines. This trend is clearly demonstrated on graphs of human population numbers, economic growth, and environmental indicators.

Demand for housing and tendencies to create compact city can be achieved with planed land use dedicated for residential collective buildings. It also requires the active construction of new ways of living together, new forms of spatial and social belonging" (Sandercock 2003, 14).

If current patterns do not change, expansion ofthe built environment will destroy or disturb naturalhabitats and wildlife on over $70 \%$ of theEarth's land surface by 2032 , driven mainly byincreas es in population, economic activity andurbanization. (UNEP2002)

In many cases CRB are harmful to workers during the construction period, as well as to occupants due to unhealthy air and indoor climate. Longer-term environmental impacts also result from CRB use and maintenance. Moreover, demolition generates enormous amounts of waste to be deposed of. 


\subsection{Study methodology}

Main methodologies used in this research are: analyze of state in context, comparison with best examples, trend analyses and DPSIR(Driving Forces-Pressures-State-Impacts-Responses).

With analyze are identified all stakeholders that participate on building process of collective residential buildings that have high impact on urban environment of Cities in region.

To identify state and actual problems is used comparative method. Urban environment in Prishtina and regional cities is compared with best international examples.

Based on trend analyses and comparis on of actual state of Prishina urban environment with good international examples are identified key causes of urban environmental destruction that can be reduced to achieve better effects. The DPSIR framework is used as a modelto identify and suggest responses needed to achieve Environmental Sustainability of Cities in region.

\section{Background and context}

Governments of Republic of Kosovo in February 2004 published report for the housing sector that points the need to develop the legal framework, institutional and economy, which will promote the solution of housing and different subject's awareness of the necessity of funding housing and general housing, as a promoter of economic development Kosovo.

In this report also is published ratio between the total individual and collective housing that give us this percentage in Kosovo: 93\% residential individual housing and collective 7\%. While the average family members is 6.5 members per household. Comparing these data with EU standards it is estimated that Kosovo lacks collective housing units. After the war the family migration towards medium and large cities and high fertility rates are the main factor that has increased the demand for housing. Lack of economic activities and other standards of life have very important social impact on rural-urban migration of families.

Despite the large number of unemployed, low income, average high for family members, high housing prices and lease, it is evident lack of mechanisms and engagement of central and local institutions in facilitating and bringing better conditions for collective residential buildings (apartment blocks/multi-family buildings).

Prishtina is experiencing population growth leading to a significant demand for housing. Due to the scarcity of designated building land, after year 1999 Prishtina has been challenged with uncontrolled settlement development in many parts of the municipality. Especially the urban peripheral of Prishtina is affected by urban sprawl. This urban sprawl has a negative impact on the urban structure of Prishtina and limits future development opportunities of the city. The unplanned settlement growth has also constrained the operability of the technical infrastructure systems and has a detrimental influence on the natural environment. Finally, the lack of building land with a clear development perspective restrains the level of private and commercial investments. Both the economy and citizens need planning reliability and safe investment conditions for the construction of residential buildings. In accordance with the Law on Spatial Planning of Kosovo, the Urban Regulatory Plans sets out the rules for the construction of buildings and other physical structures as well as for their use.

To describe and define background and context of CRBand their impact in Environmental Sustainability of Cities in region as an example is analyzed Prishtina. Housing in general and CRBis particular are analyzed in social, legal, institutional, financial, development, energy consumption and energy efficiency aspects. In the endis used DPSIR model as framework to analyze context in general.

\subsection{Social aspect:}

- Urbanization process

- Transition to trade economy

- Orientation of Government assistance for homeless families

- Replacement of informal settlements in urban zones with CRB

\subsection{Legal aspects:}

- Harmonization of sectorial Laws and draft laws with International Laws and their implementation

- Drafting of building code based on European legislation 


\subsection{Institutional aspects:}

- Education programs on Urban Environmental Sustainability

- Development of the Local and Central Sectors Report

- Networking / functional sectors between the central level and local

- Development and harmonization of strategiesbetween Municipal Housing Programs, and NationalPrograms

- Trainings for professional staff at the Central level Local and development projects in the field.

\subsection{Financial aspect:}

- Establishment of the Central Fund for Housing finance

- Creation of other mechanisms for housing finance

- Promote and strengthen the financial sector and housing credit

2.5 Development, energy consumptionand Energy Efficiencyas pect:

- Promote new construction

- Encourage the private sector to build housing, with attention to specific toCRB,

- Restoration of existing building stock

- Improving housing conditions and facilities in joint and encourage their maintenance

- Harmonization of design and planning CRBwith Kosovo's development plans

- Continuous monitoring of the current situation and development potential in this sector

\begin{tabular}{|l|c|c|}
\hline \multicolumn{1}{|c|}{ Sektor } & Kosovo (\%) & UE UE \\
\hline HOUSING & 33.34 & 26.28 \\
\hline SERVICES & 13.34 & 12.47 \\
\hline TRANSPORT & 26.52 & 30.91 \\
\hline INDUSTRY & 22.35 & 27.77 \\
\hline AGRICULTURE & 5.06 & 2.54 \\
\hline
\end{tabular}

Table 1 - Average energy consumption for all sectors (for the period 2003-2007), (Source: Workshop on energy efficiency and housing facilities)

As reported from L Berisha during Workshop on energy efficiency and housing facilities on March 25 2011: Kosovo drafted National Plan for Energy Efficiency (MEEP) 2009 -2018

As a member of the South East Europe Energy Community - Kosovo has developed the first long-term plan for EE in Kosovo, the National Plan for Energy Efficiency (MEEP) based on Directive 2006/32 / EC.

Plan has set targets for energy savings in the housing sector. Table below presents:Short-term indicative targets by the end of 2012 and long-term indicative targets until 2018. 

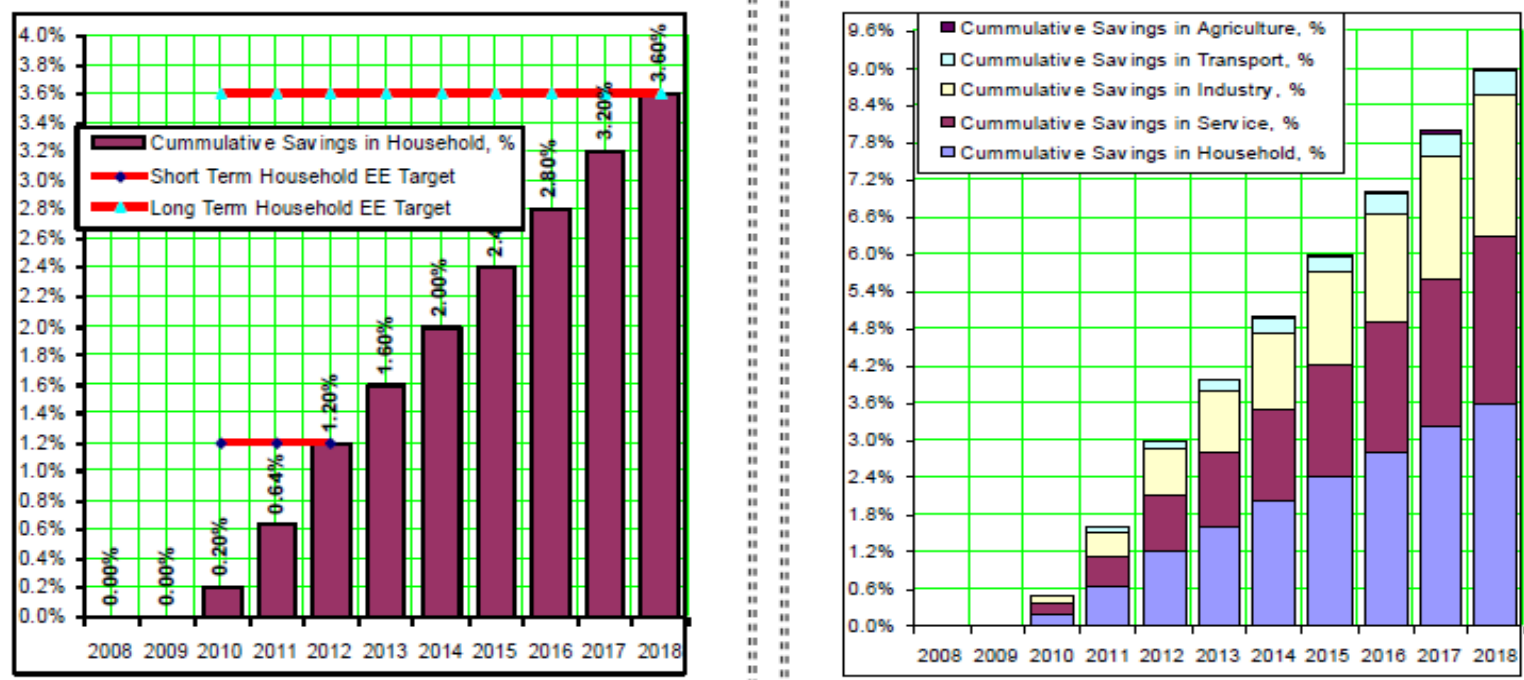

Figure 1- Short terms and long terms saving targets

(Source: Workshop on energy efficiency and housing facilities)

\begin{tabular}{|l|c|c|c|c|c|c|}
\hline \multicolumn{1}{|c|}{ State } & Legislation & $\begin{array}{l}\text { Technical } \\
\text { Regulations }\end{array}$ & $\begin{array}{l}\text { Financial } \\
\text { Instruments }\end{array}$ & $\begin{array}{l}\text { Auditory } \\
\text { Projects }\end{array}$ & $\begin{array}{l}\text { Building } \\
\text { Certification }\end{array}$ & $\begin{array}{l}\text { Information } \\
\text { campaign }\end{array}$ \\
\hline $\begin{array}{l}\text { Albania } \\
\text { Macedonia }\end{array}$ & $\mathbf{X}$ & $\mathbf{X}$ & & $\mathbf{X}$ & & \\
Bulgaria & $\mathbf{X}$ & $\mathbf{X}$ & $\mathbf{X}$ & $\mathbf{X}$ & $\mathbf{X}$ & $\mathbf{X}$ \\
\hline $\begin{array}{l}\text { Austria } \\
\text { Macedonia }\end{array}$ & $\mathbf{X}$ & $\mathbf{X}$ & $\mathbf{X}$ & $\mathbf{X}$ & $\mathbf{X}$ & $\mathbf{X}$ \\
\hline
\end{tabular}

Table 2 - Comparative analysis of policies, instruments and measures for EE in some countries in the region with the EU(Source: Workshop on energy efficiency and housing facilities)

\subsection{General aspect}

The DPSIR (Driving Forces-Pressures-State-Impacts-Res ponses) model

Collected data and information on housing and all the different elements and aspects needanalyze in new framework to assess impact in urban environmental sustainability. The DPSIRmodel is used as a framework for identifying connections between these different aspects and to describe the interactions between land use (construction of $\mathrm{CRB}$ )and urban environmental sustainability. 
DPSIR is a causal framework adopted by the European Environment Agency. The components (Fig. 2) and relations of this designed model are:

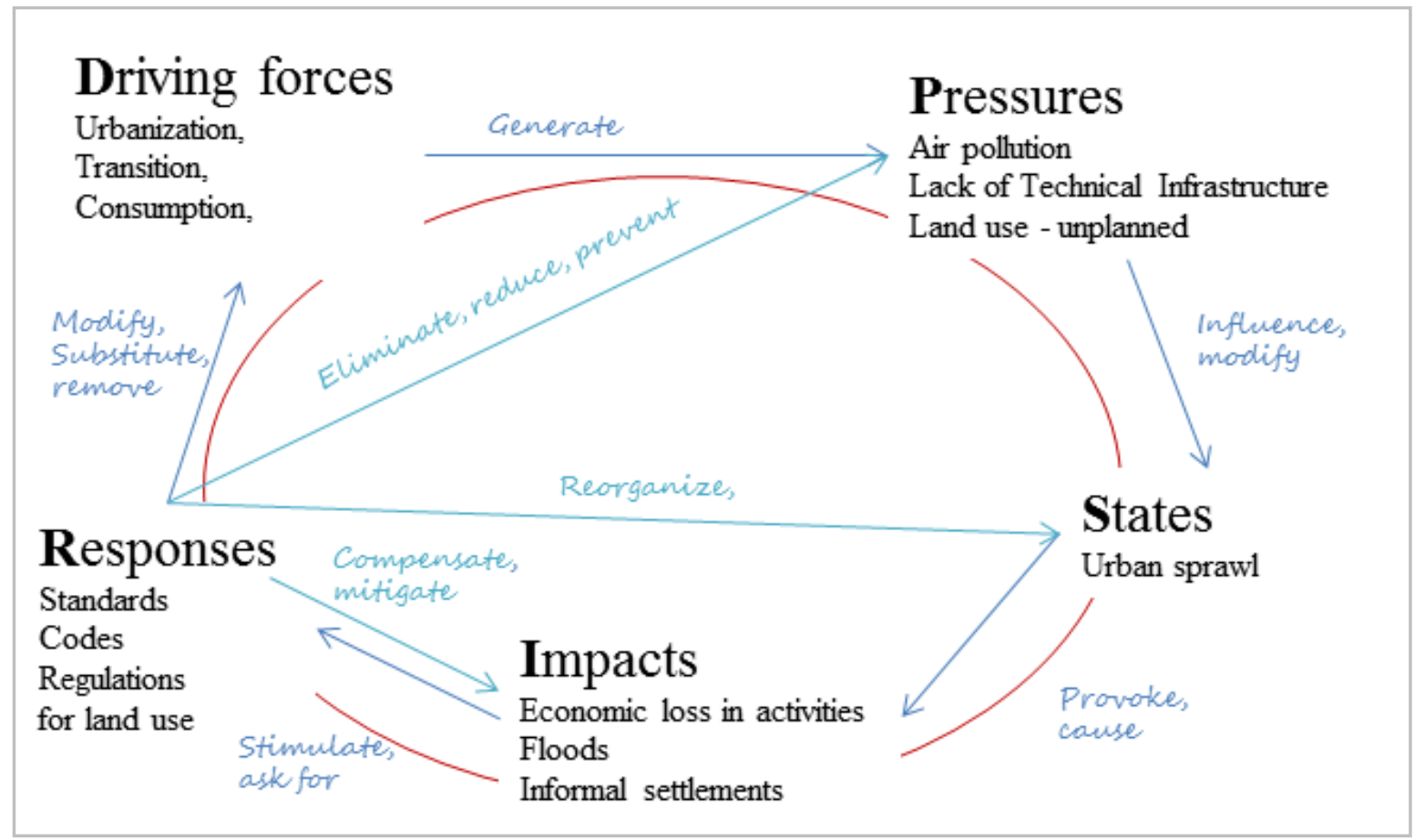

Figure 2- The DPSIR framework used to identify and suggest responses needed to achieve Environmental Sustainability of Prishtina.

\section{Suggestions}

\subsection{Areas of action}

Standards and codes for buildings and regulations for land use are main areas in short terms and long termsof action. Kosovo is far from respecting and implementing EU standards and principles.

With the establishment of the institutional framework, namely the adoption of the Law onConstruction will be defined areas of operation in all municipalities of Kosovo, and housing programs will be developed and implemented according to Strategic Development Plans of municipalities

\subsection{Establishment of Unique Building Code of the Republic of Kosovo.}

In today context necessary is to be drawn up Building code - as a legal act which provides for the establishment of minimum requirements for addressing structural power, emergency facilities, sanitation, adequate lighting and ventilation, accessibility, energy conservation and security of life in relation to new and existing facilities to protect public health, safety and general welfare of the residents. Code will be based on international standards and will include technical norms tailored to Kosovo.

Code will be drawn up by the Government under Construction Law. The code will be developed in the spirit of EU technical standards, international best practices and existing circumstances in Kosovo.

The purpose of the Code is to establish minimum requirements for the protection of public health, safety and general welfare through the resistance needed emergency space structure, balance and stability, sanitation, construction waste management, adequate lighting and ventilation, and efficiency measures energy saving, and security of life and property from fire and other hazards attributed to construction environment and to create fire safety and responsible in the event of emergencies. Code shall decide any other technical requirement that primarily considered relevant technical issues. 


\subsection{Establishment of EU regulations for buildings}

\section{Common general framework for the calculation of energy performance of buildings}

The energy performance of a building shall be determined on the bas is of the calculated or actual annual energy that is consumed in order to meet the different needs associated with its typical use and shall reflect the heating energy needs and cooling energy needs (energy needed to avoid overheating) to maintain the envisaged temperature conditions of the building, and domestic hot water needs.

The energy performance of a building shall be expressed in a transparent manner and shall include an energy performance indicator and a numeric indicator of primary energy use, based on primary energy factors per energy carrier, which may be based on national or regional annual weighted averages or a specific value for on-site production.

The methodology for calculating the energy performance of buildings should take into account European standards and shall be consistent with relevant Union legislation, including Directive 2009/28/EC.

Existing acts, regulations and standards lead the collective residential build ing industry in the right direction if they are followed up. However, to reach what can be called environmental sustainability in cities requires additional action on the policy level. This should involve providing stimulationsand dissimulations (e.g. thro ugh taxes) and funding and support for innovative businesses and technology. Special funding for good examples of collective residential builldings in Environmental Sustainability of Cities in region (Prishtina) is necessary.

\section{CONCLUSION AND DISCUSSION}

The central questions asked in this paper are as follows: can a trend towards deregulation (privatization) in the building regulatory field be observed in Europe, and are the regulatory systems converging or not? With respect to content and analysis, the paper is consistent with scientific discussions about regulatory developments in

Impact of collective residential buildings in urban environment of Prishtina (and regional cities) is very high. Role of energy efficiency measures and their combinations of measures can create synergy effects that lead to better results. Measures must be combined with land use plans for Prishtina's sustainable urbanization that requires more efficient and intensive use of land space (collective residential buildings) to accommodate the needs of a fastgrowing urban population.

Land use implications of construction are many and varied. In terms of reducing transport energy use anddemand for land, higher density building is preferable to lower density.

In accordance with Annex III to Directive 2010/31/EU and Annex I(2) to the Regulation, Kosovo (and regional cities) must define energy efficiency measures to be applied to the collective residential buildings. Measures that are submitted to the calculation will have to cover the technologies listed under Article 6 of Directive 2010/31/EU and repeated under Article 7 (last paragraph), namely decentralized supply, cogeneration, district heating and cooling and heat pumps. In accordance with paragraph 3 of Annex I (2) to the Regulation, Kosovo must also include measures based on renewable energy sources in the calculation exercise. It should be noted that no solutions might not solely linked be to achieving the energy target.

Moreover, measures acting on one system can affect the energy performance of another system. For example, the insulation level of the envelope affects the capacity and dimensions of the collective residential building systems. This interaction between different measures has to be addressed when defining building code.

It is therefore recommended that measures be combined in packages of measures and/or variants, since meaningful combinations of measures can create synergy effects that lead to better results (regarding costs and energy performance) than single measures. Variants are defined for the purpose of the delegated act as a "global result and description of a full set of measures/packages applied to a building that can be composed of a combination of measures on the building envelope, passive techniques, measures on building systems and/or measures based on renewable energy sources". 
Urban zones occupied by CRB will only be environmentally sustainable once the values of environmental sustainability have become the basis from which the majority of decisions on the creation and management of neighborhoods are made.

Policies are essential to achieve environmental sustainability in urban zones and balanced resource management. Existing policies have not led to any real shift. A large part of the problem is not the lack of sustainable building policies, but rather the need for awareness on the part of political leaders.

Of course, the impacts of buildings and construction are not all negative. Well planned structures built with sustainable methods and materials can be highly beneficial to both communities and workers. The most notable social benefit is the provision of construction jobs, especially for low-skilled and/or entry-level workers.

The success of the new concept and principles relies heavily on a healthy growing urban economy and a strong real estate market as the main drivers to improved health and poverty alleviation (lessmoney spent on energy means more money tospend on education and nutrition).

\section{REFERENCES}

Anink, D., et al. (1996) The Handbook of Sustainable Building: Ecological Choice of Materials in Construction and Renovation. James and James (Science Publishers), London.

Barnard, N. (1994) Dynamic energy storage in the building fabric. BSRIA TR 9/94. ISBN 0860223728

Brand, Stewart (1994) How Buildings Learn: What Happens After They're Built. Viking, New York

Rawlings, R. (1999) Ground-source heat pumps. BSRIA TN 18/99.ISBN 0860225062.

Sandercock, L (2003) Cosmopolis II: Mongrel Cities in the 21st Century, London: Continuum (ISBN 0826470459 and 0826464637 (pbk.))

UNEP/Earthscan (2002) Global EnvironmentalOutlook 3. London. http://en.wikipedia.org/wiki/Sustainable_design\#Sustainable_architecture 